\title{
CATOT RACA

\section{PERANCANGAN SISTEM PENGOLAHAN DATA TERPADU BERBASIS CLIENT SERVER DI PAUD USWATUN HASANAH BENGKULU}

\author{
Anisa Tri Wahyuni ${ }^{1)}$; Sapri' ${ }^{2}$; Dimas AuliaTringgana ${ }^{2)}$ \\ 1) Study Program of Informatics Faculty of Computer Science, \\ Universitas DehasenBengkulu \\ 2) Department of Informatics, Faculty of Computer Science, Universitas \\ DehasenBengkulu \\ Email: ${ }^{1)}$ anisatriwahyuni25@gmail.com
}

\section{How to Cite :}

Anisa Tri Wahyuni; Sapri; Dimas AuliaTringgana. 2020. PERANCANGAN SISTEM PENGOLAHAN DATA TERPADU BERBASIS CLIENT SERVER DI PAUD USWATUN HASANAH BENGKULU. GATOTKACA Journal.DOI:https://doi.org/10.37638/gatotkaca.1.1.1-12

\section{ARTICLE HISTORY \\ Received [12Januari 2020] \\ Revised [16 Februari 2020] \\ Accepted [20 Maret 2020]}

\section{KEYWORDS}

Keywords:Client Server , PHP and MYSQL
This is an open access article under the $C C-B Y$ SA license

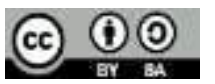

\section{ABSTRAK}

PAUD Uswatun Hasanah Kota Bengkulu merupakan salah satu lembaga pendidikan yang menyelenggarakan Program TK, Kober, TPA, SPS. Selama ini proses pengolahan data di PAUD masih menggunakan cara konvensional yaitu dengan mengisi formulir pendaftaran calon peserta didik, pendataan calon peserta didik, guru, hingga pembayaran uang rutin SPP. Dengan proses pengolahan data tersebut, terdapat masalah yang muncul yaitu sering terjadi kehilangan arsip data. Sistem pengolahan data terpadu berbasis client server pada PAUD Uswatun Hasanah Bengkulu dibuat menggunakan bahasa pemrograman PHP dan Database MySQL. Aplikasi ini digunakan untuk membantu proses pengolahan data, sehingga mempermudah admin dalam proses pengarsipandanpengambil an data.

\section{ABSTRACT}

PAUD UswatunHasanah Bengkulu City is one of the educational institutions that organizes TK, Kober, TPA, SPS Programs. During this time the data processing in PAUD still uses conventional methods, namely by filling in the registration forms of prospective students, data collection of prospective students, teachers, to routine payment of SPP money. With the data processing, there is a problem that arises that is often the loss of data files. Integrated client server based data processing system in UswatunHasanah PAUD Bengkulu was made using the PHP programming language and MYSQL Database. This application is used to assist data processing, making it easier for admins in the process of archiving and retrieving data. 


\section{PENDAHULUAN}

Dalam era globalisasi saat ini, teknologi sudah menjadi kebutuhan bagi masyarakat, masyarakat tidak bisa lepas dari teknologi dalam kehidupan sehari-hari untuk membantu mempermudah pekerjaan. Salah satu teknologi yang sering digunakan saat ini adalah Teknologi Informasi, teknologi yang digunakan hampir di semua bidang termasuk dalam bidang pendidikan.

Pendidikan memiliki peranan penting dalam menjamin kelangsungan hidup negara dan bangsa, karena pendidikan merupakan penentu kualitas sumber daya manusia. Teknologi informasi dapat memberikan kemudahan dalam mengembangkan pendidikan yang lebih efektif, efisien, kompetitif, dan produktif yang berarti juga ikut membantu dalam meningkatkan kualitas sumber daya manusia itu sendiri.

Oleh karena itu dunia pendidikan dituntut untuk selalu bisa mengikuti perkembangan Teknologi Informasi untuk bisa mewujudkan hal tersebut, sehingga keterkaitan antara pendidikan dan Teknologi Informasi ini tidak bisa dipisahkan jika ingin membuat suatu pendidikan yang lebih baik.

PAUD Uswatun Hasanah Kota Bengkulu merupakan salah satu lembaga pendidikan yang menyelenggarakan Program TK, Kober, TPA, SPS. Selama ini proses pengolahan data di PAUD masih menggunakan cara konvensional yaitu dengan mengisi formulir pendaftaran calon peserta didik, pendataan calon peserta didik, guru, hingga pembayaran uang rutin SPP. Dengan proses pengolahan data tersebut, terdapat masalah yang muncul yaitu sering terjadi kehilangan arsip data karena data administrasi tidak disimpan dengan baik, dan juga sering kesulitan dalam pembuatan rekapan laporan dari hasil pengolahan data yang telah dilakukan.

Oleh karena itu untuk membantu proses pengolahan data tersebut, maka dalam penelitian akan dirancang sebuah sistem pengolahan data terpadu berbasis client server, di mana pengguna dapat mengakses aplikasi melalui web secara intranet dengan link website yang akan ditentukan.

Berdasarkan uraian tersebut, maka penulis tertarik untuk mengangkat judul penelitian yaitu tentang "Perancangan Sistem Pengolahan Data Terpadu Berbasis Client Server Di PAUD Uswatun Hasanah Bengkulu”.

\section{LANDASAN TEORI}

\section{Pengolahan Data Terpadu}

Perangkat lunak yang terintegrasi adalah program tunggal yang berisi "modul" atau "alat" untuk menyelesaikan banyak aplikasi bisnis, aplikasi ini mencakup pengolahan kata, spreadsheet, manajemen database, grafis, dan komunikasi. Modul pengolahan kata dapat digunakan untuk mengetik surat atau laporan. Modul spreadsheet dapat digunakan untuk melakukan analisis keuangan atau merekam perbandingan. Modul database dapat digunakan untuk mengatur inventarisasi, untuk mengompilasi sebuah daftar pelanggan, alamat, e-mail, telepon dan nomor faks. Sebuah modul grafis dapat memberikan seorang individu atau bisnis keunggulan dengan menyediakan alat-alat yang akan memberikan terlihat profesional untuk dokumen yang dihasilkan (Priyantodkk, 2017).

\section{Client Server}

Client-Server merupakan model jaringan komputer-komputer yang cukup popular dan masih digunakan hingga saat ini. Dalam terminologi komputer, server adalah komputer yang menjadi pusat atau sentral layanan dalam jaringan komputer, sedangkan klien adalah anggota jaringan komputer. Klien dapat berupa komputer, 
printer, atau perangkat lain yang bekerja dalam jaringan komputer. Jadi jaringan clientserver adalah suatu jaringan komputer yang melibatkan (komputer) server dan client.Client Server adalah suatu arsitektur dimana sumber daya server menyediakan $\mathrm{k}$ omputasi untuk banyak komponen client.Client dan Server bisa berjalan pada mesin ya ng sama atau berbeda,ditulis dalam berbagai bahasa dan menggunakan sistem operas i yang berbeda.

\section{Web Server}

Web Server atau server web merupakan sebuah perangkat lunak server yang berfungsi menerima permintaan dari klien yang dikenal dengan browser web dan mengirimkan kembali hasilnya dalam bentuk halaman-halaman web melalui protokol HTTP atau HTTPS. Web server bertugas mengelola halaman-halaman web dan dokumen-dokumen lainnya. Jadi pada dasarnya web server hanyalah sebuah perangkat lunak yang bisa saja berada di komputer apapun dengan spesifikasi apapun. PC biasapun dapat berfungsi sebagai web server (Priyantodkk, 2017).

Untuk menguji apakah aplikasi web berjalan baik atau tidak maka diperlukan yang disebut web server. Web server ini adalah tempat dimana akan menyimpan aplikasi web, kemudian mengaksesnya melalui internet. Setiap perubahan, kecil maupun besar, upload ke web server baru setelah itu diperiksa apakah perubahan itu sudah sesuai dengan yang diinginkan atau belum

Server Web dibutuhkan untuk melakukan pemrograman yang membutuhkan teknologi server-side, seperti PHP, ColdFusion, ASP, dan JSP. Oleh karena itu, server web merupakan perangkat yang penting untuk melakukan uji coba pemrograman server-side yang dibuat. Pemrograman server-side biasanya digunakan untuk mengakses database yang terdapat pada server hosting, sehingga pengembang dengan mudah mengelola content website dengan mudah tanpa mengubah halamanhalaman web.

Selain itu dibutuhkannya web server ini adalah karena untuk server side script seperti PHP, pemeriksaan baru akan tampil jika menggunakan web server. Inilah bedanya dengan client side script seperti HTML, CSS, dan Javascript yang cukup dengan browser sudah bisa tahun apakah script sudah sesuai dengan keinginan atau belum.Ada banyak web server yang bisa menjadi pilihan. Di windows ada Internet Information Service (IIS) keluaran dari Microsoft. Aplikasi web server ini sudah support ASP.NET dan PHP. Web server lain yang sangat terkenal adalah Apache. Apache sebetulnya merupakan salah satu proyek dari sebuah yayasan yang memiliki banyak proyek software gratis untuk digunakan banyak orang. Yayasan itu bernama The Apache Software Foundation.

\section{PHP}

PHP (Hypertext Preprocessor), merupakan bahasa pemrograman pada sisi server yang memperbolehkan programmer menyisipkan perintah-perintah perangkat lunak web server (Apache, IIS, atau apapun) akan dieksekusi sebelum perintah itu dikirim oleh halaman ke browser yang me-request-nya, contohnya adalah bagaimana memungkinkannya memasukkan tanggal sekarang pada sebuah halaman web setiap kali tampilan tanggal dibutuhkan. Sesuai dengan fungsinya yang berjalan di sisi server maka PHP adalah bahasa pemrograman yang digunakan untuk membangun teknologi web application (Antonio dkk, 2012). 


\section{Adobe Dreamweaver}

Adobe Dreamweaver merupakan aplikasi pengembang yang berfungsi untuk mendesain web yang dibuat, dikembangkan, dan diproduksi oleh Adobe System. Aplikasi pengembang web ini sangat digemari oleh web desainer dalam merancang web sebab perangkat lunak komputer ini memiliki kelebihan dan kemudahan dalam penggunaannya. Dengan menggunakan aplikasi ini, pengembangan web dapat dilakukan secara visual, sehingga hasil perancangan web dapat langsung terlihat tanpa harus menggunakan aplikasi bantu peramban seperti Google Chrome, Firefox atau Internet Explorer. Teknologi web yang didukung oleh Adobe Dreamweaver sangat beragam, salah satunya adalah teknologi untuk kebutuhan pengembangan web berbasis mobile (Antonio dkk, 2012).

\section{DFD}

Data Flow Diagram adalah suatu network yang menggambarkan suatu sistem automat/komputerisasi, kanalisasi, atau gabungan dari keduanya, yang penggambarannya disusun dalam bentuk kumpulan komponen sistem yang saling berhubungan sesuai dengan aturan mainnya. Keuntungan penggunaan DFD adalah memungkinkan untuk menggambarkan sistem dari level yang paling tinggi kemudian menguraikannya menjadi level yang lebih rendah (dekomposisi). Sedangkan kekurangan penggunaan DFD adalah tidak menunjukkan proses pengulangan (looping), proses keputusan dan proses perhitungan (Sutabri, 2012).

\section{ERD}

Model data dengan diagram hubungan entitas (Entity Relationship Diagram/ER-D) adalah suatu pemodelan berbasis pada persepsi dunia nyata yang mana terdiri dari kumpulan objek dasar yang disebut dengan entitas (entity) dan hubungan Siantar objek-objek tersebut dengan menggunakan perangkat konseptual dalam bentuk diagram. Sebuah entitas adalah objek yang dibedakan dari objek yang lain oleh himpunan dari atribut (Sutabri, 2012).

\section{METODE PENELITIAN}

\section{Metode Pengumpulan Data}

Metode pengumpulan data yang digunakan dalam penelitian ini, antara lain :

a. Observasi

Penulis datang langsung untuk melihat dan mengevaluasi proses pengolahan data yang selama ini dilakukan oleh PAUD Uswatun Hasanah Kota Bengkulu.

b. Wawancara

Penulis melakukan wawancara dengan memberikan pertanyaan-pertanyaan yang terkait dengan masalah yang akan dibahas kepada Ketua PAUD Uswatun Hasanah Kota Bengkulu.

c. Studi Pustaka

Studi pustaka adalah suatu metode pengumpulan data yang diambil dari perpustakaan atau instansi yang berupa karya ilmiah, jurnal, buku-buku yang berhubungan dengan penulisan ini.

\section{Analisis Sistem Aktual}




\section{GATOT WAGA

PAUD Uswatun Hasanah Kota Bengkulu merupakan salah satu lembaga pendidikan yang menyelenggarakan Program TK, Kober, TPA, SPS. Selama ini proses pengolahan data di PAUD masih menggunakan cara konvensional yaitu dengan mengisi formulir pendaftaran calon peserta didik, pendataan calon peserta didik, guru, hingga pembayaran uang rutin SPP. Dengan proses pengolahan data tersebut, terdapat masalah yang muncul yaitu sering terjadi kehilangan arsip data karena data administrasi tidak disimpan dengan baik, dan juga sering kesulitan dalam pembuatan rekapan laporan dari hasil pengolahan data yang telah dilakukan.

\section{Analisis Sistem Baru}

Sistem baru merupakan pengembangan dari sistem lama untuk mengatasi permasalahan yang terdapat pada sistem lama. Sistem baru yang dimaksud adalah dengan merancang sistem pengolahan data terpadu berbasis client server di PAUD Uswatun Hasanah Bengkulu, di mana pengguna dapat mengakses aplikasi melalui web secara intranet dengan link website yang akan ditentukan.

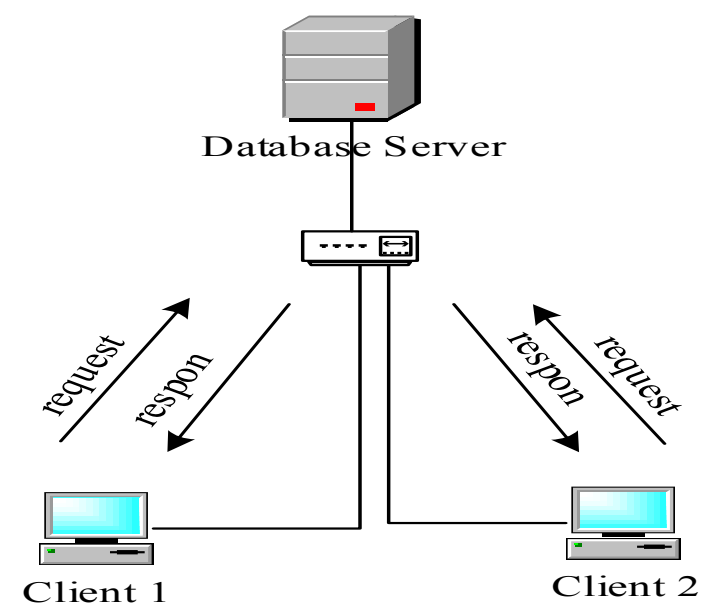

Gambar 1. Skema Jaringan

\section{DFD}




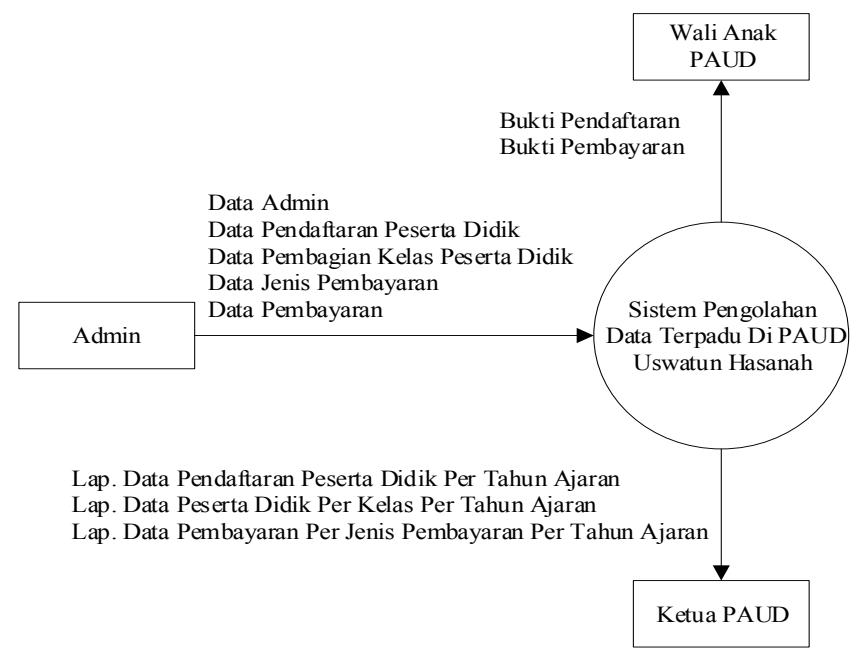

\section{Gambar 2 . Diagram Konteks}

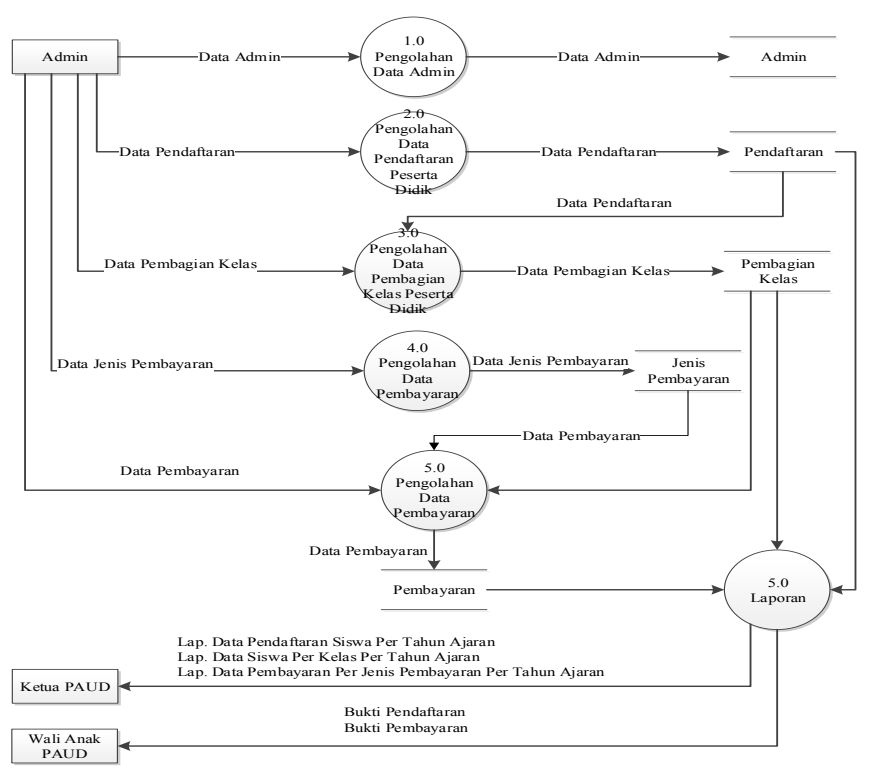

Gambar 3. DFD Level ERD 


\section{CATOU RAGA}

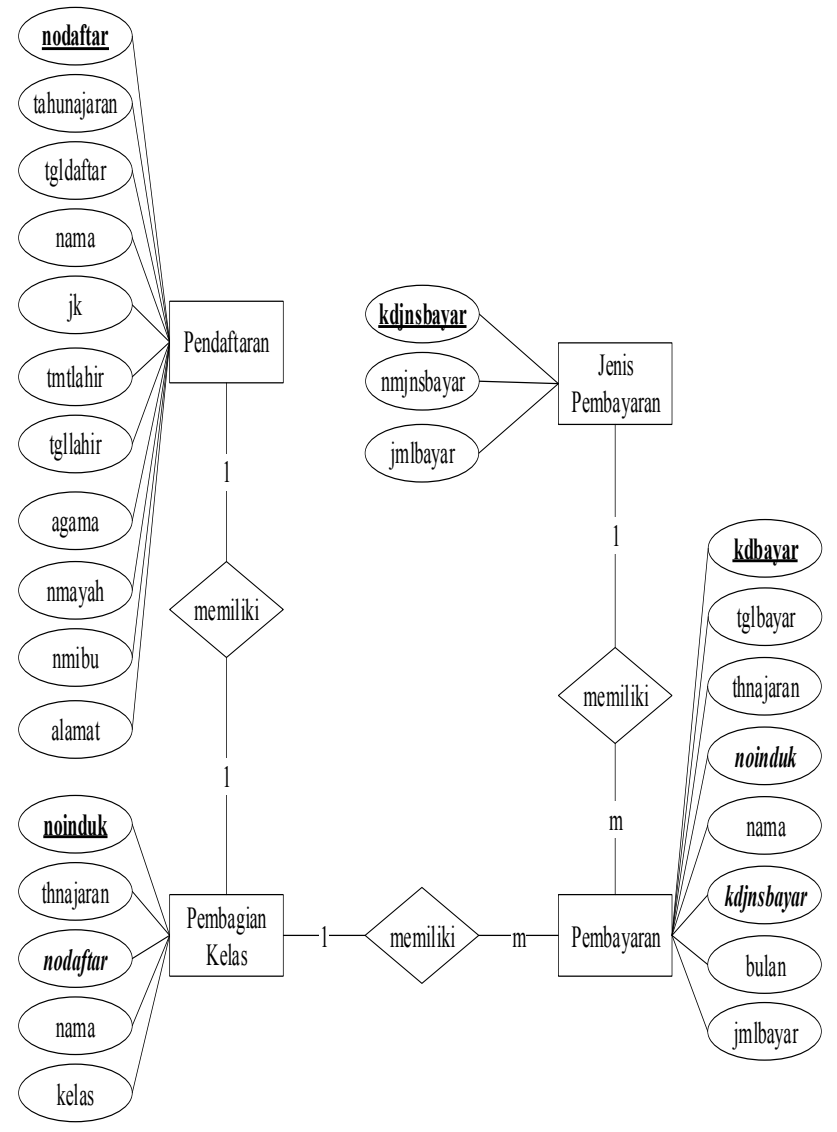

Gambar 4. ERD

\section{HASILDAN PEMBAHASAN}

\section{Pembahasan}

Sistem pengolahan data terpadu berbasis client server di PAUD Uswatun Hasanah Bengkulu merupakan salah dibuat menggunakan bahasa pemrograman PHP dan Database MySQL. Aplikasi ini digunakan untuk membantu proses pengolahan data yang meliputi beberapa fitur, antara lain :

1. Dapat melakukan proses pengolahan data pendaftaran peserta didik

2. Dapat melakukan proses pembagian kelas pada masing-masing peserta didik yang sudah mendaftar dan diterima.

3. Dapat melakukan proses pengolahan data jenis pembayaran uang sekolah

4. Dapat melakukan proses pembayaran uang sekolah masing-masing peserta didik

Sistem pengolahan data terbadu ini berbasis client server, sehingga peneliti membangun jaringan sesuai dengan skema jaringan yang terdapat pada BAB sebelumnya, dimana terdapat 3 komputer/laptop yang terhubung satu sama lain melalui switch, dengan ketentuan sebagai berikut :

IP : 192.168.1.1 = sebagai server

IP : 192.168.1.2 = sebagai client 
IP : 192.168.1.3 = sebagai client

Halaman login digunakan untuk membatasi akses pengguna aplikasi, sehingga dibutuhkan username dan password yang benar agar dapat mengakses halaman menu utama.

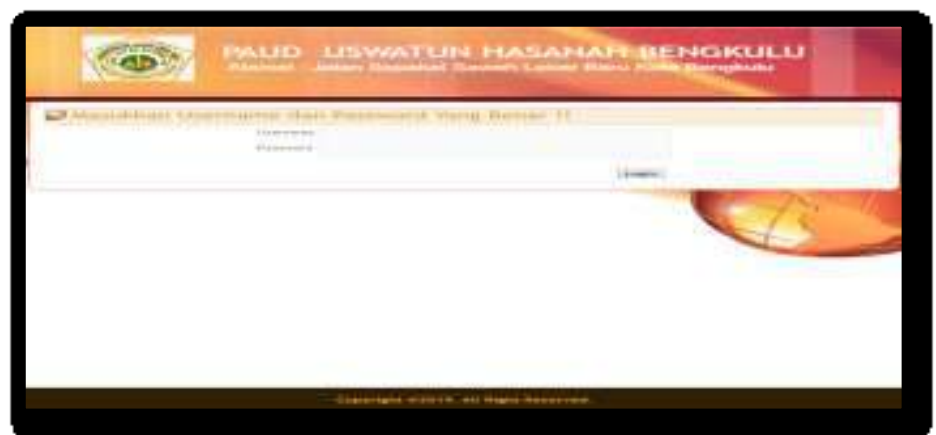

Gambar 4. Menu Login

Halaman menu utama memiliki sub menu yang dapat digunakan oleh admin untuk mengakses pengolahan data pada aplikasi.

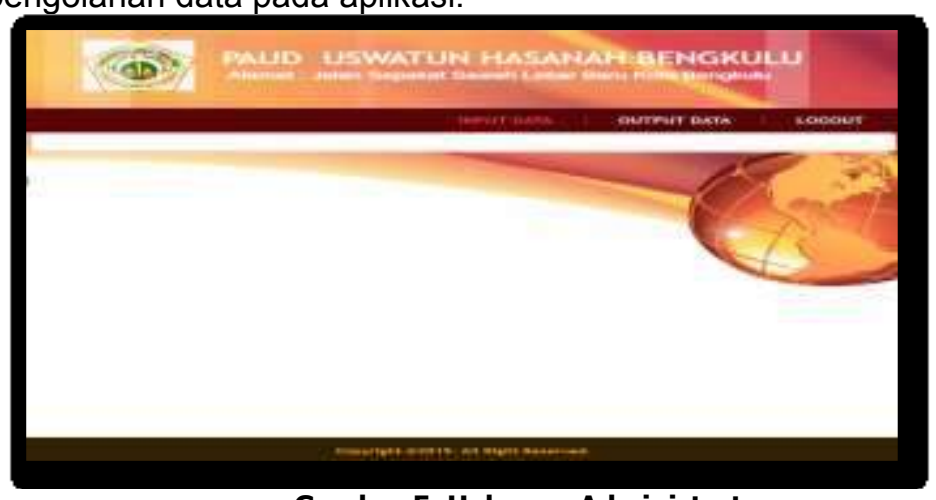

Gambar 5. Halaman Administrator

Digunakan untuk mengolah data admin dengan cara menambah, mengubah, serta menghapus data admin yang akan mengakses aplikasi

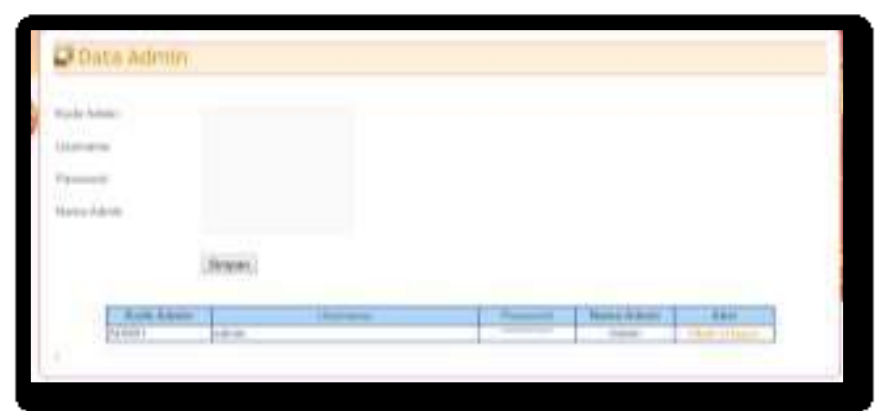

Gambar 6. Halaman Data Admin

Digunakan untuk mengolah data pendaftaran peserta didik dengan cara menambah, mengubah serta menghapus data pendaftaran. 


\section{GATOT RACA गOURNALL}

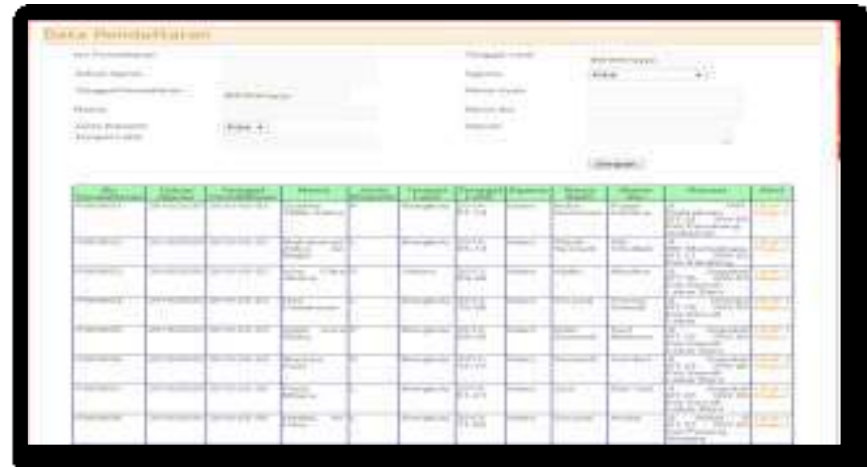

Gambar 7. Halaman Data Pendaftaran Peserta Didik

Digunakan untuk mengolah data pembagian kelas peserta didik berdasarkan data pendaftaran peserta didik yang telah dilakukan sebelumnya. Proses pengolahan data dapat dilakukan dengan cara menambah, mengubah, serta menghapus data pembagian kelas peserta didik.

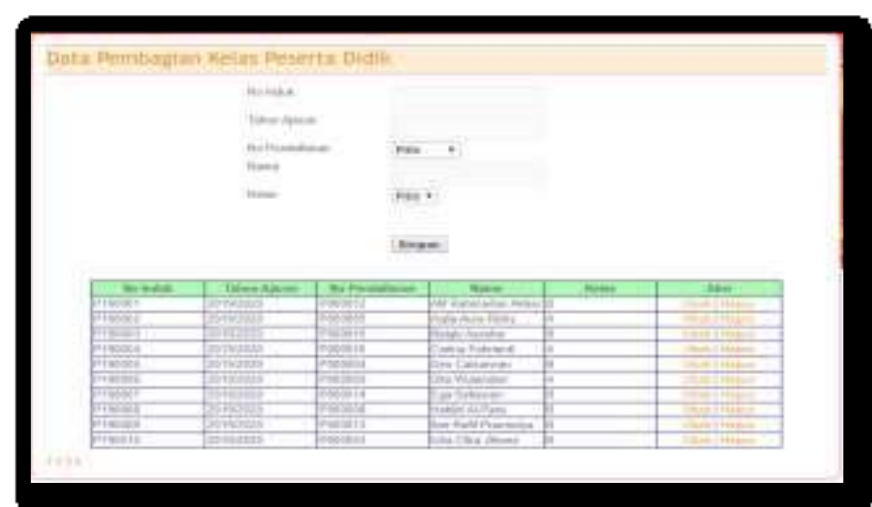

Gambar 8. Halaman Pembagian Kelas Peserta Didik

Digunakan untuk mengolah data jenis pembayaran uang sekolah di PAUD Uswatun Hasanah, dengan cara menambah, mengubah, serta menghapus data jenis pembayaran.

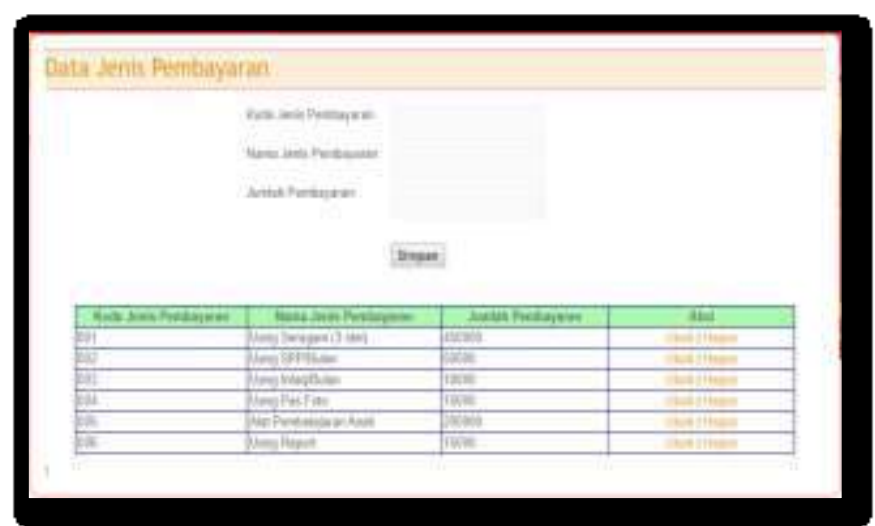

Gambar 9. Halaman Jenis Pembayaran 
Digunakan untuk mengolah data pembayaran uang sekolah berdasarkan jenis pembayaran yang dibayarkan. Proses pengolahan data pembayaran dapat dilakukan dengan cara menambah, mengoreksi serta menghapus data pembayaran.

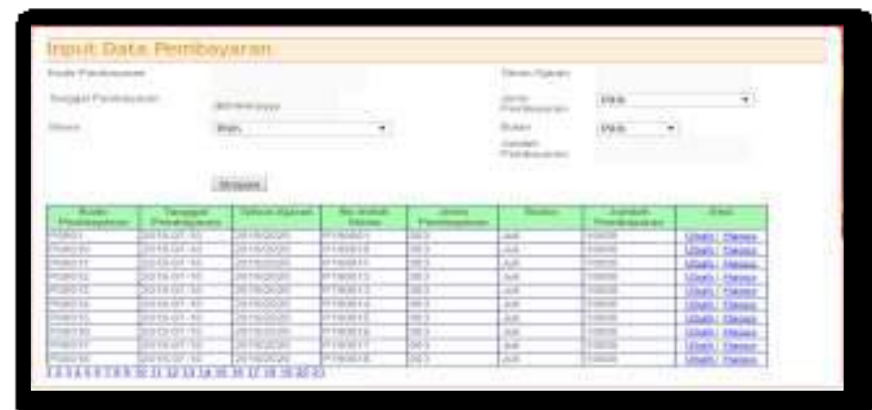

Gambar 10. Output

Menampilkan informasi bukti pendaftaran berdasarkan data pendaftaran peserta didik.

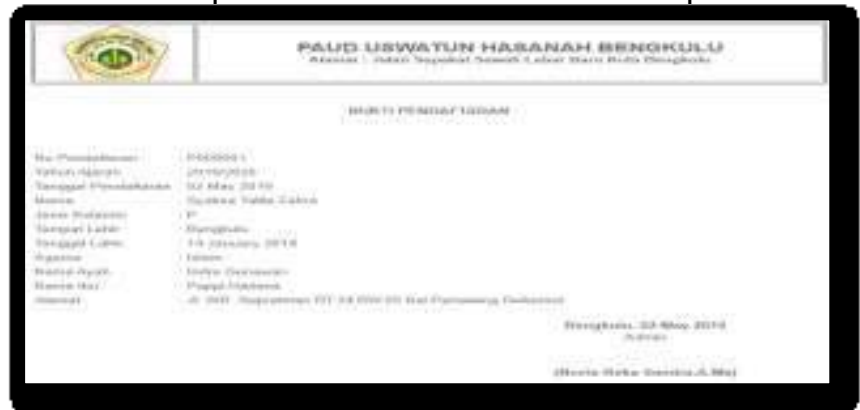

Gambar 11. Output

Informasi butki pembayaran berdasarkan jenis pembayaran uang sekolah yang dibayarkan oleh peserta didik.

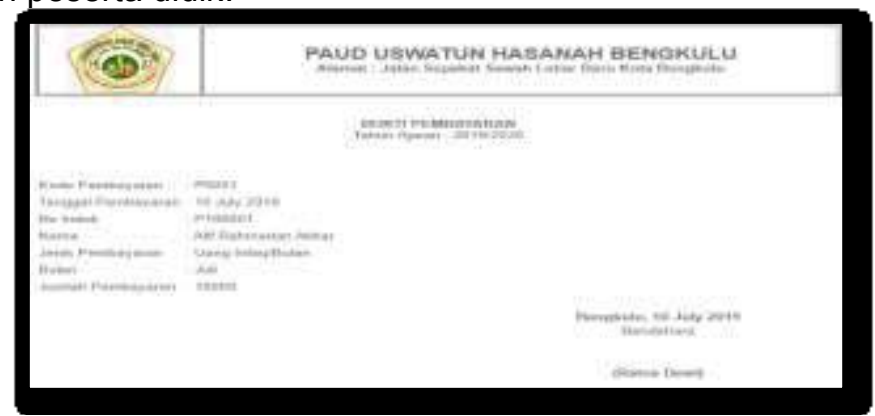

Gambar 12. Output

Informasi laporan data pendaftaran peserta didik berdasarkan tahun ajaran. 


\section{GAHOT RACA

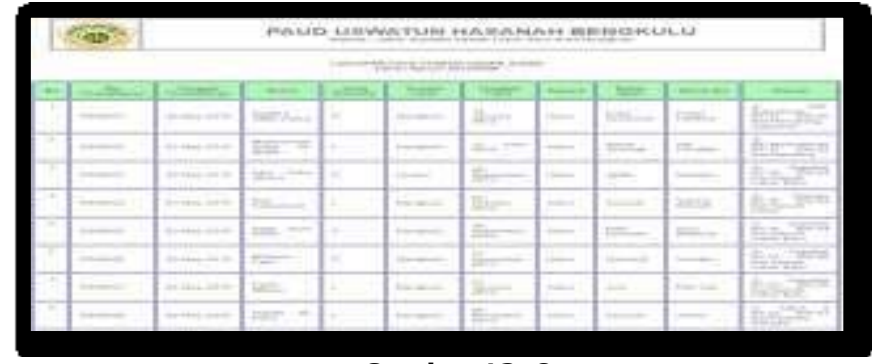

Gambar 13. Output

Menampilkan informasi laporan data peserta didik berdasarkan kelas dan tahun ajaran.

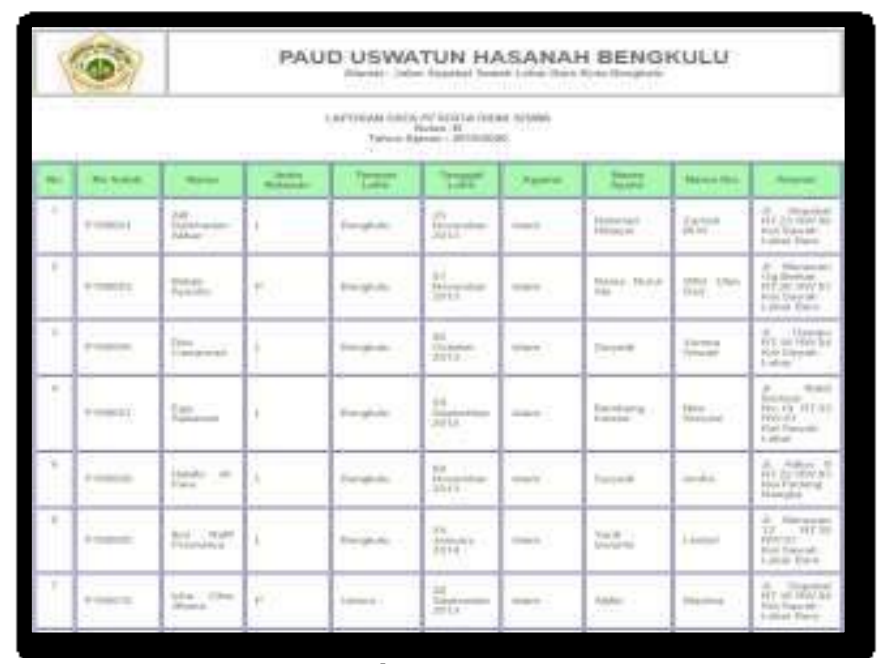

Gambar 14. Output

Berdasarkan hasil pengujian yang telah dilakukan, Sistem pengolahan data terpadu berbasis client server di PAUD Uswatun Hasanah Bengkulu sudah berjalan sebagaimana mestinya melalui jaringan LAN berbasis client server.

\section{KESIMPULAN DAN SARAN}

\section{Kesimpulan}

Berdasarkan hasil dari pembahasan tersebut, maka dapat disimpulkan bahwa :

1. Sistem pengolahan data terpadu berbasis client server di PAUD Uswatun Hasanah Bengkulu merupakan salah dibuat menggunakan bahasa pemrograman PHP dan Database MySQL. Aplikasi ini digunakan untuk membantu proses pengolahan data yang meliputi beberapa fitur, yaitu dapat melakukan proses pengolahan data pendaftaran peserta didik, dapat melakukan proses pembagian kelas pada masingmasing peserta didik yang sudah mendaftar dan diterima, dapat melakukan proses pengolahan data jenis pembayaran uang sekolah, dapat melakukan proses pembayaran uang sekolah masing-masing peserta 
2. Berdasarkan hasil pengujian yang telah dilakukan, Sistem pengolahan data terpadu berbasis client server di PAUD Uswatun Hasanah Bengkulu sudah berjalan sebagaimana mestinya melalui jaringan LAN berbasis client server.

3. Selain itu pengujian juga dilakukan pada saat demo program ke PAUD Uswatun Hasanah Bengkulu melalui form kuisioner (data terlampir). Dari hasil kuisioner tersebut, dapat disimpulkan bahwa aplikasi ini dapat membantu PAUD Uswatun Hasanah Bengkulu dalam mengelola data pendaftaran hingga pembayaran uang sekolah peserta didik.

\section{Saran}

Berdasarkan penelitian yang penulis lakukan, maka penulis menyarankan agar dapat menggunakan Sistem pengolahan data terpadu berbasis client server di PAUD Uswatun Hasanah Bengkulu ini untuk mempermudah dalam proses pengelolaan data dengan cara multi user.

\section{DAFTAR PUSTAKA}

Antonio, Harianto, dkk. 2012. Rancang Bangun Sistem Informasi Administrasi Informatika (SI-ADIF). Jurnal ELKHA Vol.4 No.2 Oktober 2012. Universitas Tanjungpura.

Hidayatullah, Priyanto. Kawistara, Jauhari Khairul. 2017. Pemrograman Web Edisi Revisi. Penerbit Informatika : Bandung

Mandar, Ruko. 2017. Solusi Tepat Menjadi Pakar Adobe Dreamweaver CS6. PT. Elexmedia Komputindo : Jakarta

Putri, Nency Extise. Azpar, Supriandi. 2017. Sistem Informasi Pengolahan Data Pendidikan Anak Usia Dini (PAUD) Terpadu Amalia Syukra Padang. Jurnal Edik Informatika Vol 2 ISSN 2407-0493

Sutabri, Tata. 2012. Analisis Sistem Informasi. Penerbit Andi : Yogyakarta. 